\title{
Impacts of Land use on Selected Physicochemical Properties of Soils of Gindeberet Area, Western Oromia, Ethiopia
}

\author{
Lechisa Takele $^{1 *}$, Achalu Chimdi ${ }^{2}$ and Alemayehu Abebaw ${ }^{1}$ \\ ${ }^{1}$ Department of Chemistry, College of Natural and Computational Sciences, Ambo University, PO Box: 19, \\ Ambo, Ethiopia \\ ${ }^{2}$ College of Natural and Computational Sciences, Wollega University, P.O Box: 395, Nekemte, Ethiopia
}

\begin{abstract}
This study was carried out with the objective of determining impact of land uses on selected soil physicochemical properties of Gindeberet area, Western Ethiopia. Disturbed and undisturbed surface soil samples $(0-20 \mathrm{~cm})$ were collected from each land use type and examined for their analysis of soils physicochemical properties. Soil samples were analyzed at Ambo University Chemistry Laboratory. Standard procedures were employed for the analyses of selected soil properties. Soil pH ranged from 4.88 (cultivated land) to 5.65 (forest land). Soil bulk density was ranged from 1.09 (forest land) to $1.28\left(\mathrm{~g} / \mathrm{cm}^{3}\right)$ (cultivated lands). Mean organic matter ranged from 1.38 (cultivated land) to $2.01 \%$ (forest land). Mean soil available phosphorus ranged from 2.23 (cultivated land) 4.30ppm (forest land). Mean total nitrogen ranged from $0.08 \%$ (cultivated land) to $0.11 \%$ (forest land). Mean soil exchangeable calcium and magnesium ranged from 8.16 (cultivated land) to $13.44 \mathrm{cmol}\left({ }^{+}\right) / \mathrm{kg}$ (forest land) and 3.54 (cultivated land) to $\left.5.33 \mathrm{cmol}^{+}\right) / \mathrm{kg}$ (forest land) respectively, while mean soil exchangeable potassium and sodium ranged from 0.28 (cultivated land) to $0.71 \mathrm{cmol}\left({ }^{+}\right) / \mathrm{kg}$ (forest land) and 0.36 (cultivated land) to $0.75 \mathrm{cmol}\left({ }^{+}\right) / \mathrm{kg}$ (forest land) respectively. The CEC ranged from 7.63 (cultivated land) to $16.53 \mathrm{cmol}\left({ }^{+}\right) / \mathrm{kg}$ (forest land).Mean available iron, manganese, zinc and copper ranges from 37.08 to $37.71,22.18$ to $37.70,4.79$ to 6.39 and 1.88 to 2.49 respectively. All available micronutrients are higher in forest land and lower in cultivated land. The study pointed out that, the difference between different land use type on soil moisture content, $\mathrm{pH}$, cation exchange capacity, organic carbon, total nitrogen, available phosphorus and exchangeable bases. From the present study, it could be concluded that the soil quality and health were maintained relatively under the forest land, whereas the influence on most soil parameters were negative on the cultivated land, indicating the need for employing integrated soil fertility management in sustainable manner to optimize and maintain
\end{abstract} the favorable soil physicochemical properties.

Article Information Article History:

Received : 01-10-2014

Revised : 15-12-2014

Accepted : 28-12-2014

Keywords:

Gindeberet

Land use types

Soil properties

Surface soil

${ }^{*}$ Corresponding Author:

Lechisa Takele

E-mail:

lechisat@gmail.com

Copyright@2014 STAR Journal. All Rights Reserved.

\section{INTRODUCTION}

Soil fertility is a critical issue to the farmers, particularly where population pressure is high and agriculture is the main source of income. As a result of recent changes in agricultural practices and increasing resource of constraints Ethiopia is facing a serious problem of soil quality decline. Low soil fertility in Ethiopia has been attributed to low inherent soil quality, loss of nutrients through erosion, crop harvests and little or no addition of external inputs in the form of organic or inorganic fertilizers. This is particularly evident in the intensively cultivated areas (Achalu et al., 2012).

Land use conversion may cause important change in soil characteristics and can increase soil erosion or cause soil compaction (Neill et al., 1997). Effect of conversion of forest land into pasture land on soil organic matter is variable, in some cases an increase has been reported for certain locations (Lemenih et al., 2005), decreasing in others (Powers et al., 2004). Land use changes mostly focused on deforestation, cropland expansion, dry land degradation, urbanization, pasture expansion and agricultural intensification. In tropical region forest cleared for the expansion of cropland, wood extraction and infrastructure expansion (Bridges and Bakker, 1997).

Land use change also affects the productivity of a soil. These manifests as changes in soil properties such as the contents of availability of macro and micro nutrient, organic matter, CEC and it also affects the soil structure (Aluko and Fagbenro, 2000). Agricultural sustainability requires a periodic evaluation of soil fertility status this is important in understanding factors which impose serious constraints to increased crop production under different land use types and for adoption of suitable land management practices. 
Lechisa Tekele et alo,

Knowledge about an up-to-dated status of soil physical and chemical properties of different land use systems plays a vital role in enhancing production and productivity of the agricultural sectors on sustainable basis. However, practically oriented basic information on the status and management of soil physic-chemical properties as well as their effect on soil quality to give recommendations for optimal and sustainable utilizations of land resources remains poorly understood. Therefore, this study was conducted with specific objective to assess and explore the status of soil physic-chemical characteristics of three different land use systems of representative area of Western Oromia Region. The result of this study expected to add value to the up-to-date scientific documentation of the status of soil fertility and soil quality of different land uses of the study area and other similar agro-ecological environments in the country.
Sci. Technol. Arts Res. J., Oct-Dec 2014, 3(4): 36-41

\section{MATERIALS AND METHODS}

Description of the Study Area

The study is situated in Gindeberet District, West Shawa Zone of Oromiya National Regional State, Ethiopia, between astronomical grids of $9^{\circ} 21^{\prime}$ to $9^{\circ} 50^{\prime} \mathrm{N}$ and $37^{\circ} 37^{\prime}$ to $38^{\circ} 08^{\prime} \mathrm{E}$ (PEDOWS, 1997). The District town, Kachisi $\left(9^{0} 32^{\prime} \mathrm{N}\right.$ and $\left.37^{\circ} 49^{\prime} \mathrm{E}\right)$ is geographically located approximately at the centre of the District 193 $\mathrm{Km}$ west of Addis Ababa.

Ten years trends of rainfall distribution showed that there was no even distribution of rainfall in each year. Rather it was highly fluctuated between the ranges of 882$2039 \mathrm{~mm}$. the same is true for temperature which was varied from 21 to 25.9 and 5.6 to $9.2{ }^{\circ} \mathrm{C}$ for the maximum and minimum temperature respectively.

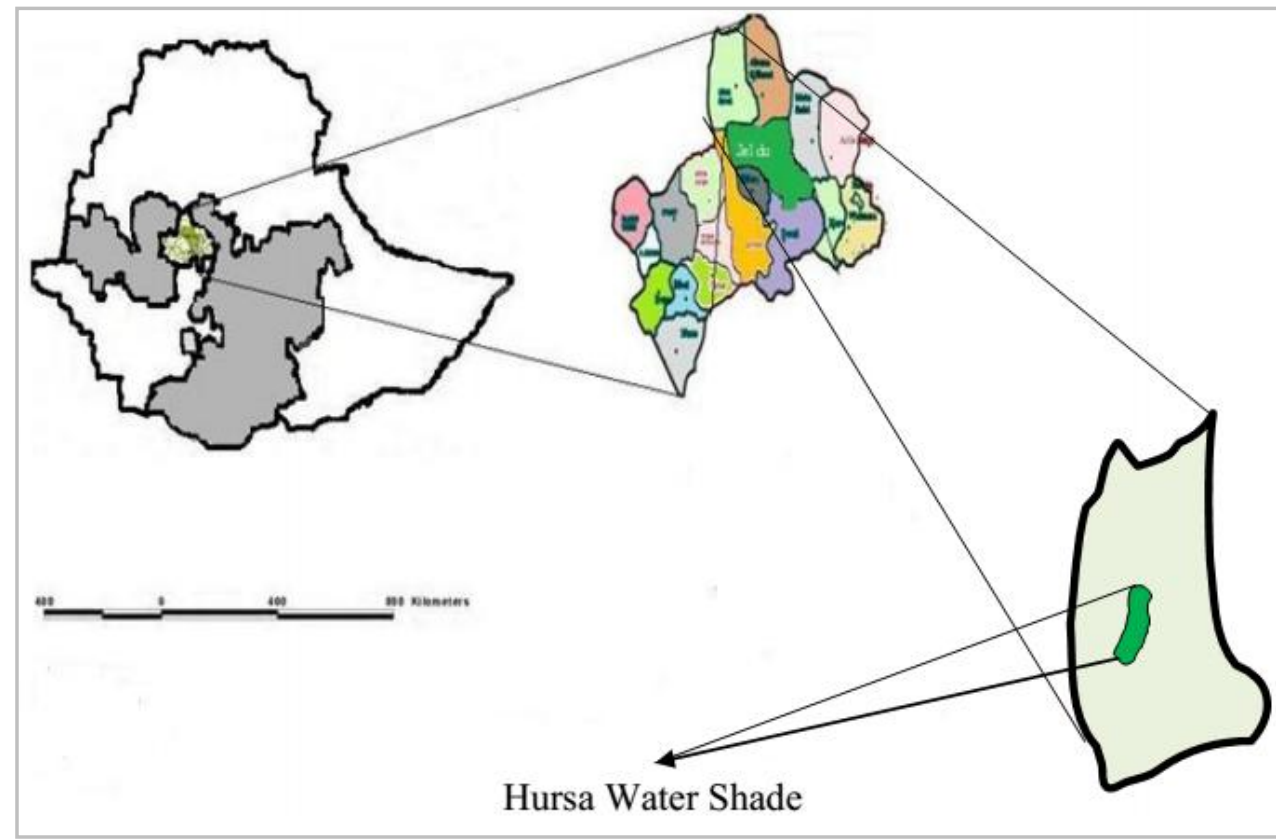

Figure 1: Location map of study area

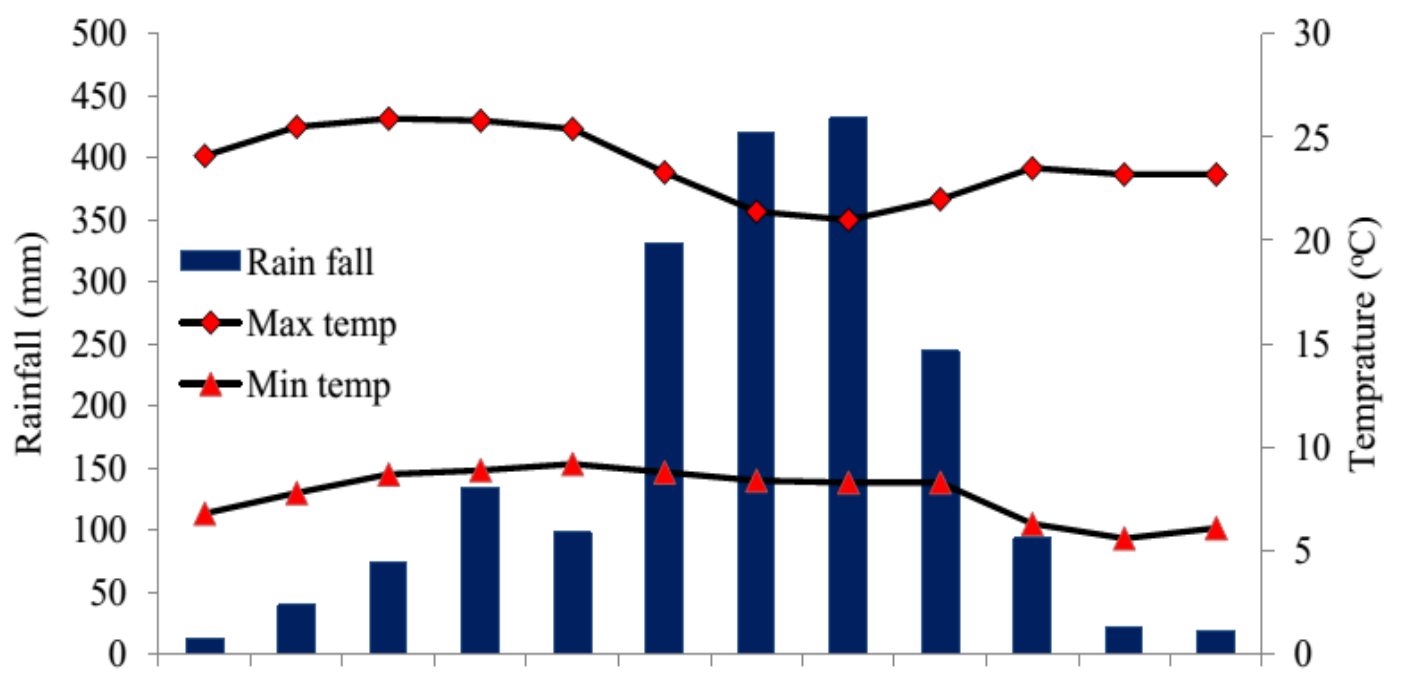

Jan Feb Mar App May Jun Jul Aug Sep Oct Nov Dec

Months

Figure 2: Mean monthly rainfall and mean maximum and minimum temperatures of the study area 


\section{Soil Sampling and Analysis}

Composite top soil $(0-20 \mathrm{~cm})$ samples from representative site of each land use in three replicates were collected in 2013/2014. Samples were air dried ground and passed through $2 \mathrm{~mm}$ sieve for analysis. Analysis of soil samples were carried out at Chemistry laboratory of Ambo University based on their standard laboratory procedure. Particle size distribution and bulk density were determined by the hydrometer and the core sample methods respectively. Soil $\mathrm{pH}$ was determined in soil to water ratio of 1:2.5 (w/v). The OC was determined by wet digestion method. Total $\mathrm{N}$ was determined by micro-Kjeldahl wet digestion and distillation method, while available $\mathrm{P}$ was extracted by the Bray II method and finally quantified by spectrophotometer. Cation exchange capacity (CEC) and exchangeable bases were extracted by $1 \mathrm{M}$ ammonium acetate $(\mathrm{pH} 7)$ method. Exchangeable bases $(\mathrm{Ca}, \mathrm{Mg}, \mathrm{Na}$, and $\mathrm{K}$ ) were extracted with $1 \mathrm{M}$ ammonium acetate at $\mathrm{pH}$ 7. $\mathrm{Ca}$ and $\mathrm{Mg}$ were analyzed by titrations using EDTA method. Exchangeable $\mathrm{K}$ and $\mathrm{Na}$ were measured by flame photometer. Available micronutrients ( $\mathrm{Fe}, \mathrm{Mn}, \mathrm{Zn}$ and $\mathrm{Cu}$ ) of the soil were extracted by diethylene triamine pentaacitic acid (DTPA) method and determined using AAS at their respective wavelength.

\section{Statistical Analysis}

Soil physicochemical properties were subjected to analysis of variance using statistical analysis system version 9.0 (SAS, 2004). Treatment means of the different land use types were compared according to Tukey test. Pearson's simple correlation coefficient was executed to reveal the magnitudes and directions of relationship between different parameters of soil properties within and among land use types.

\section{RESULTS AND DISCUSSION \\ Impact of Land Use on Selected Physical Properties of the Soils}

The results of the study revealed that the textural class of all land use types was clay (Table 1), indicating the similarity in parent material. However, clay content varied significantly $(P<0.05)$ among the land use types. Its content was significantly lower in forest land as compared to the cultivated and grazing lands. Similarly, Achalu (2012) reported higher clay content in cultivated land than the adjacent soils under grazing land and natural forest. Higher mean clay fraction recorded in the cultivated land attributed to the impacts of deforestation and farming practices (Chikezie et al., 2009). Silt content of forest land was significantly higher than both cultivated and grazing land $(P=0.05)$. High sand content was observed under grazing land while low sand content was observed under cultivated land. Similarly, an increase in soil bulk density by $21.42 \%$ due to deforestation and subsequent cultivation was observed in cultivated land compared to forest land. On the other hand, soils under cultivated land significantly higher in bulk density than soils under forest and grazing lands (Akamigbo, 1999; Onweremadu et al., 2009, Achalu, 2012). Similarly, Islam and Weil (2000) stated that bulk density increased significantly with increasing cultivation period.

Table 1: Mean values of particle size distribution and bulk density as influenced by the different land uses

\begin{tabular}{lccccc}
\hline \multirow{2}{*}{ Land use types } & \multicolumn{2}{c}{ Particle size distribution (\%) } & \multirow{2}{*}{ Textural class } & \multirow{2}{*}{$\mathbf{\rho b}\left(\mathbf{g} / \mathbf{c m}^{\mathbf{3}}\right)$} \\
\cline { 2 - 5 } & Sand & Silt & Clay & & \\
\hline Forest land & $22.46 \pm 4.18^{\mathrm{b}}$ & $30.09 \pm 2.07^{\mathrm{a}}$ & $47.45 \pm 5.00^{\mathrm{a}}$ & Clay & $1.09 \pm 0.02^{\mathrm{c}}$ \\
Cultivated land & $21.16 \pm 3.85^{\mathrm{a}}$ & $19.10 \pm 1.88^{\mathrm{b}}$ & $59.74 \pm 6.69^{\mathrm{a}}$ & Clay & $1.28 \pm 0.02^{\mathrm{a}}$ \\
Grazing land & $25.15 \pm 2.88^{\mathrm{c}}$ & $24.93 \pm 2.97^{\mathrm{b}}$ & $49.92 \pm 2.81^{\mathrm{a}}$ & Clay & $1.24 \pm 0.01^{\mathrm{b}}$ \\
\hline
\end{tabular}

Means within column followed by different letters are significantly different $(P=0.05)$ with land use types. pb $=$ bulk density.

\section{Soil pH, Organic Matter, Total Nitrogen, C:N Ratio and Available Phosphorus}

Soil pH significantly affected across land use types $(P$ $=0.05)$. Generally the $\mathrm{pH}$ ranges 5.65 to 4.88 among the land use types (Table 2). The $\mathrm{pH}$ value under forest land was found to be the highest followed by grazing land and cultivated land respectively. The soil $\mathrm{pH}$ could be categorized as strongly acidic under cultivated land and grazing land whereas that of forest land was moderately acidic following the classification described by Brady and Weil (2002). The lower value of soil $\mathrm{pH}$ under the cultivated land may be due to the depletion of basic cations in crop harvest and due to its highest microbial oxidation that produces organic acids, which provide $\mathrm{H}$ ions to the soil solution lowers its soil $\mathrm{pH}$ value.

Analysis of variance revealed that, soil OM contents under various land use types were significantly $(P=0.05)$ different from each other (Table 2). Soil organic matter contents under grazing and cultivated land were lower than the OM content of corresponding soils under forest land. It can be concluded that, under the cultivated land uses, losses of forest derived soil organic matter were not fully compensated by organic matter input from the cereal crop residues. A relatively lower level of disturbance in grazing land soils has apparently led to an increase in organic matter content as compared to those cultivated soils. Though absence of such soil disturbance minimizes rapid loss of soil OM, export of nutrients and low biomass return after grazing have contributed much to its decline compared to observations made in the forest land (Weldeamlak and Stroosnijder, 2003; Genxu et al., 2004).

The soil total $\mathrm{N}$ was significantly affected across all land use types $(P=0.05)$. The contents of total $N$ for cultivated and grazing lands were medium while, the mean value of total $\mathrm{N}$ was high $(0.11 \%)$ in forest land. However, the content under cultivated land was significantly lower $(0.08 \%)$ than the other land use types (Table 2). Such result is expected since most soil nitrogen is bound in organic carbon. In line with this (Yifru, 2011) reported that, total $\mathrm{N}$ content of soils under cultivation were lower compared to contents in the natural forest soils. The increase in soil total nitrogen contents of forest land might be due to the vegetation cover which improved the soil organic matter contents.

The available phosphorus did not show any significant difference in cultivated and grazing lands $(P=0.05)$, however, it was significantly different in forest land. 
Lechisa Tekele et alo,

Generally the mean value of available phosphorus was significantly higher (4.30 ppm) in forest land followed by grazing and cultivated land (2.52 ppm), (2.236 ppm) respectively. The cultivated land showed $9 \%$ variation in
Sci. Technol. Arts Res. J., Oct-Dec 2014, 3(4): 36-41

overall mean available $P$ content from the forest land which obviously could be due to crop mining, crop residue removal and erosion.

Table 2: Mean values of $\mathrm{pH}$, soil organic matter (OM), total $\mathrm{N}(\mathrm{TN}), \mathrm{C}: \mathrm{N}$ ratio and available $\mathrm{P}$ as influenced by the different land uses

\begin{tabular}{lccccc}
\hline & pH & OM (\%) & TN (\%) & Av. P(Ppm) & C: N \\
\hline Forest land & $5.65 \pm 0.26^{\mathrm{a}}$ & $2.01 \pm 0.41^{\mathrm{a}}$ & $0.11 \pm 0.02^{\mathrm{b}}$ & $4.30 \pm 0.27^{\mathrm{b}}$ & $9.62 \pm 0.02^{\mathrm{c}}$ \\
Cultivated land & $4.88 \pm 0.23^{\mathrm{c}}$ & $1.38 \pm 1.25^{\mathrm{b}}$ & $0.08 \pm 0.05^{\mathrm{a}}$ & $2.23 \pm 0.01^{\mathrm{c}}$ & $10.28 \pm 0.02^{\mathrm{a}}$ \\
Grazing land & $5.32 \pm 0.09^{\mathrm{b}}$ & $1.84 \pm 0.09^{\mathrm{b}}$ & $0.09 \pm 0.02^{\mathrm{a}}$ & $2.52 \pm 0.03^{\mathrm{a}}$ & $12.74 \pm 0.01^{\mathrm{b}}$ \\
\hline
\end{tabular}

Means within column followed by different letters are significantly different $(P=0.05)$ with land use types.

Carbon to nitrogen ratio $(\mathrm{C}: \mathrm{N})$ of a soil is obtained by dividing the organic carbon to total nitrogen. The concentration of either of two is expressed in same unit. In this study, $\mathrm{C}: \mathrm{N}$ ratio of the soil in the study area was insignificant at all land use types $(P=0.05)$. The $\mathrm{C}: \mathrm{N}$ ratio of the soil ranges from 12.74 to 9.62 in grazing and forest lands respectively (Table 2 ) which can be due to the rapid loss of $\mathrm{N}$ in the former. Thus, one can understand that the impact of land use and associated management was more pronounced in soil nitrogen than organic carbon. The present finding was in line with (Yihenew and Getachew, 2013) who reported highest values of C: N contents under grazing land use in northwestern Ethiopian soils.

\section{Cation Exchange Capacity and Exchangeable Bases}

As per the ratings recommended by Hazelton and Murphy (2007), the CEC value of the forest land was moderate where as grazing land and cultivated lands were classified as low status of CEC value. Cation exchangeable capacity was significant in all land use types $(P=0.05)$ (Table 3$)$. Generally the highest cation exchangeable capacity was observed in forest land (16.53 cmol( $\left.\left.{ }^{+}\right) \mathrm{kg}^{-1}\right)$ followed by grazing land $\left.\left(14.41 \mathrm{cmol}^{+}\right) \mathrm{kg}^{-1}\right)$ while the lowest was observed in cultivated land (7.63 cmol $\left.\left({ }^{+}\right) \mathrm{kg}^{-1}\right)$.

The relatively high CEC values was recorded, in forest land may attributed to the fact that soil in forest land accumulate high percent $\mathrm{OC}$ and has greater capacity to hold cations thereby resulted greater potential fertility in the soil. Therefore, soil CEC is expected to increase through improvement of the soil OM content. However, deforestation, overgrazing and changing of land from forest to crop land without proper management aggravates soil fertility reduction in the cultivated land. The result of the present study concurs with the findings of (Achalu et al., 2012) who reported highest CEC value in soils of forest land and lowest under cultivated land.

The study on exchangeable cations revealed that all the cations did not show similar trends throughout the land use types. The exchangeable $\mathrm{Mg}$ content of forest land was significantly higher than other land uses, but it was not significant for grazing land soil at $P=0.05$. In general exchangeable $\mathrm{Mg}$ contents of different land use types were ranged from $\left.3.54 \mathrm{cmol}^{+}\right) \mathrm{kg}^{-1}$ to $5.33 \mathrm{cmol}\left({ }^{+}\right)$ $\mathrm{kg}^{-1}$ (Table 3). According to (Jones, 2003) the exchangeable $\mathrm{Mg}$ content of the study area is rated as medium. The result demonstrated that the exchangeable magnesium contents were well maintained in the forest ecosystem due to nutrient recycling when compared to grazing and cultivated lands, where basic nutrients loss upon grazing and harvesting prevailed. Exchangeable $\mathrm{Mg}$ were significantly influenced by soil depths at $(P=0.05)$. Exchangeable $\mathrm{Mg}$ was insignificantly decreased with increasing depths along all soil depths.

The exchangeable calcium (exchangeable $\mathrm{Ca}$ ) content of different land use types was significant at $(P=0.05)$. Exchangeable $\mathrm{Ca}$ ranges from $\left.8.16 \mathrm{cmol}^{+}\right) \mathrm{kg}^{-1}$ to 13.44 $\left.\mathrm{cmol}^{+}\right) \mathrm{kg}^{-1}$ (Table 3). Similar to exchangeable $\mathrm{Mg}$, the Ex. Ca was high in forest land and low in cultivated land. The Low content of exchangeable $\mathrm{Ca}$ in cultivated field attributed to soil erosion and abundant crop harvest for the past three decades which contributed for the depletion of $\mathrm{Ca}$ in the cultivated lands. The exchangeable $\mathrm{Ca}$ is medium for cultivated land soil while, The exchangeable $\mathrm{Ca}$ content of forest and grazing lands were rated as high (Jones, 2003). The present studies are in line with (Teshome et al., 2013) who observed highest and lowest exchangeable $\mathrm{Ca}$ in forest and cultivated lands respectively in western Ethiopia of Ababo area.

Table 3: Comparison of cation exchange capacity, exchangeable bases in different land use types. Results expressed as mean \pm standard deviation

\begin{tabular}{lccccc}
\hline \multirow{2}{*}{ Land use types } & \multicolumn{5}{c}{ Available micro nutrients(mg/kg) } \\
\cline { 2 - 6 } & Exchangeable Ca & Exchangeable Mg & Exchangeable Na & Exchangeable K & CEC \\
\hline Forest land & $13.44 \pm 1.08^{\mathrm{a}}$ & $5.33 \pm 0.31^{\mathrm{a}}$ & $0.75 \pm 0.30^{\mathrm{a}}$ & $0.71 \pm 0.04^{\mathrm{a}}$ & $16.53 \pm 1.24^{\mathrm{a}}$ \\
Cultivated land & $8.16 \pm 0.43^{\mathrm{c}}$ & $3.54 \pm 0.27^{\mathrm{b}}$ & $0.36 \pm 0.18^{\mathrm{a}}$ & $0.28 \pm 0.05^{\mathrm{c}}$ & $7.63 \pm 1.64^{\mathrm{c}}$ \\
Grazing land & $11.54 \pm 0.98^{\mathrm{b}}$ & $4.36 \pm 0.47^{\mathrm{c}}$ & $0.57 \pm 0.18^{\mathrm{a}}$ & $0.56 \pm 0.07^{\mathrm{b}}$ & $14.41 \pm 1.46^{\mathrm{b}}$ \\
\hline
\end{tabular}

Means within column followed by different letters are significantly different $(P=0.05)$ with land use types.

\section{Available Micronutrients}

The micronutrients status of the soils was influenced by different land use types (Table 4). Significant variations $(P=0.05)$ in overall available manganese $(\mathrm{Mn})$ with respect to forest land was observed among different land use types. The highest overall mean available $\mathrm{Mn}$ was measured under forest land $(37.70 \mathrm{mg} / \mathrm{kg})$ followed by grazing land $(27.98 \mathrm{mg} / \mathrm{kg})$ while cultivated land contained the smallest $(22.18 \mathrm{mg} / \mathrm{kg})$ available $\mathrm{Mn}$. The higher a manganese content of forest land was attributed 
to anaerobic microbial respiration (Paul and Clark, 1996), in addition to this (Zhangn et al., 2005) reported soil organic matters are the main source of available manganese. The concentration of $\mathrm{Mn}$ was in the toxic level in all land use systems, as the concentrations of $\mathrm{Mn}$ in all land use types were greater than $22.18 \mathrm{mg} / \mathrm{kg}$ compared to the critical level of $5 \mathrm{mg} / \mathrm{kg}$. This higher content of $\mathrm{Mn}$ could be attributed due to $\mathrm{pH}$ of the soil where $\mathrm{Mn}$ becomes more available in acidic soils.

Iron $(\mathrm{Fe})$ content of the soil was insignificantly affected by different land use types $(P=0.05)$. The value of $\mathrm{Fe}$ in the soil of the three land use types were 37.71, 37.54 and $37.08 \mathrm{mg} / \mathrm{kg}$ for grazing, forest and cultivated lands respectively. Result showed that, concentration of $\mathrm{Fe}$ in soil of grazing land was higher as compared to soil from both forest and cultivated lands. In the study area, Fe contents under various land uses were above critical level of $4.5 \mathrm{mg} \mathrm{kg}^{-1}$ (Kparmwang et al., 2000) or 2.5-5.0 (Sims and Johnson, 1991). This indicates that Fe deficiency is not likely a problem as have been reported by others for most acid soils.

The zinc $(\mathrm{Zn})$ content of the soil was also insignificantly influenced by different land use types $(P=0.05)$. The mean value of $\mathrm{Zn}$ in the soils of the three land use types were 6.39, 5.31 and 4.79 for forest, cultivated and grazing lands respectively. Thus the availability of $\mathrm{Zn}$ increased as phosphorus, nitrogen and SOM content increases in the soil may be due to the formation of organic complexes between organic matter and $\mathrm{Zn}$ that protect it from leaching. Specifically, the availability of $\mathrm{Zn}$ increased with $\mathrm{OM}$ content which might be ascribed to greater availability of chelating agents through $\mathrm{OM}$ which implied that Organo mineral complexes, particularly metallic ions such as $\mathrm{Fe}^{2+}, \mathrm{Cu}^{2+}$, $\mathrm{Zn}^{2+}$, and $\mathrm{Mn}^{2+}$. These results were similar to the findings of Yifru (2010).

Table 4: Comparison of micro nutrients in different land use types. Results expressed as mean \pm standard deviation

\begin{tabular}{ccccc}
\hline \multirow{2}{*}{ Land use types } & \multicolumn{4}{c}{ Available micro nutrients(mg/kg) } \\
\cline { 2 - 5 } & $\mathbf{F e}$ & $\mathbf{M n}$ & $\mathbf{Z n}$ & $\mathbf{C u}$ \\
\hline Forest land & $37.54 \pm 1.34^{\mathrm{a}}$ & $37.70 \pm 1.53^{\mathrm{a}}$ & $6.39 \pm 1.05^{\mathrm{a}}$ & $2.49 \pm 1.10 \mathrm{a}$ \\
Cultivated land & $37.08 \pm 1.57^{\mathrm{c}}$ & $22.18 \pm 2.88^{\mathrm{c}}$ & $5.31 \pm 1.68^{\mathrm{b}}$ & $1.88 \pm 0.93 \mathrm{c}$ \\
Grazing land & $37.71 \pm 0.95^{\mathrm{b}}$ & $27.98 \pm 1.56^{\mathrm{b}}$ & $4.79 \pm 1.67^{\mathrm{b}}$ & $2.00 \pm 0.46 \mathrm{a}$ \\
\hline
\end{tabular}

Copper (Cu) contents of different soil was insignificantly influenced by land use types $(P=0.05)$. The mean value of Cu content varies from $2.49,2.00$ and 1.88 for forest, grazing and cultivated lands respectively (Table 5). Forest land contained high $\mathrm{Cu}$ contents while cultivated land contained the lowest $\mathrm{Cu}$. This is attributed to the strong association of copper with SOM. The present study was in line with (Wakene, 2006) who reported decrease of $\mathrm{Cu}$ across soil depths from top to bottom surface of Western Ethiopian Alfisols of Bako. The $\mathrm{Cu}$ contents correlated negatively with clay, bulk density, $\mathrm{K}$ and $\mathrm{Na}(0.95,0.75,0.87$ and 0.71$)$ respectively.

\section{CONCLUSIONS}

The soil moisture content of the forest land was significantly higher than cultivated and grazing lands. There was also significant change in soil bulk density in which the forest land contained lower soil bulk density. Sand and clay contents of the textural class were significantly affected by land use. Generally, the textural classifications of the soils of the study area were clay type. The soil chemical properties of the study area were significantly affected by land use types except exchangeable $\mathrm{Na}$, which was insignificantly influenced by land use types. The SOM content was observed high in forest land but it was low cultivated land. The analysis of soil $\mathrm{pH}$ of the cultivated land showed that it was more acidic than the grazing land. Mean exchangeable $\mathrm{Ca}$ and exchangeable $\mathrm{K}$ were significantly influenced by different land use types while exchangeable $\mathrm{Mg}$ and exchangeable $\mathrm{Na}$ were insignificantly influenced by different land use types. The micronutrient status of different land use types were insignificantly influenced by land use types except for available $\mathrm{Mn}$ of forest land which was significantly influenced by land use types. From the present study, it could be concluded that the soil quality and health were maintained relatively under the forest land, whereas the influence on most parameters were negative on the soils of the cultivated land, suggesting the need for intervention so as to optimize and sustain the soil quality in the case of cultivated land. Special emphasis should be given for the management of soil $\mathrm{OM}$ as many physicochemical properties are correlated with it. Based on the study on the selected soil physicochemical properties showed that they are low for cultivated land; this implies that inputs either in the form of organic or inorganic fertilizer needs to be added adequately so that the cultivated land will continue to give better productivity.

\section{REFERENCES}

Achalu, C., Heluf, G., Kibebew, K., Abi, T. (2012). Status of selected physicochemical properties of soils under different land use systems of Western Oromia, Ethiopia. Journal of Biodiversity and Environmental Sciences 2(3): 57-71.

Akamigbo, F.O.R. (1999). Influence of land use on soil properties of the humid tropical agro-ecology of Southeastern Nigeria. Niger Agricultural Journal 3(30): 59-76.

Aluko, A.P. and Fagbenro, J.A. (2000). The role of tree species and land use systems in organic matter and nutrient availability in degraded Ultisol of Onne, Southeastern Nigeria. Annual Conference of Soil Science Society, Ibadan, Oyo State

Brady N.C. and Weil R.R. (2002). The nature and properties of soils, $13^{\text {th }}$ Ed. Prentice- Hall Inc., New Jersey, USA.

Chikezie, A., Eswaran, H., Asawalam, D.O. and Ano, A.O. (2009). Characterization of the benchmark soils of contrasting parent materials in Abia State, Southeastern Nigeria. Global Journal of Pure and Applied Sciences 16(1): 23-29. 
Lechisa Tekele et alo,

Genxu, W., Haiyan, M., Ju, Q. and Juan, C. (2004). Impact of land use changes on soil carbon, nitrogen and phosphorus and water pollution in an arid region of northwest China. Soil use and Management 20: 3239.

Hazelton, P. and Murphy, B. (2007). Interpreting Soil Test Results: What Do All the Numbers Mean? $2^{\text {nd }}$ Edition. Csiro publishing, Australia. 152p.

Islam, K.R. and Weill, R.R. (2000). Land use effect on soil quality in tropical forest ecosystem of Bangladesh. Agriculture, Ecosystems and Environment 79 1): 9-16.

Jones, B. J. (2003). Agronomic Handbook: Management of Crops, Soils, and Their Fertility. CRC Press LLC. 450p.

Kparmwang, T., Raji, B.A. and Odenze, A.C. (2000). Extractable micronutrients in some soils developed on sandstone and shale in the Benue Valley, Nigeria. Journal of Soil Research 1: 42-48.

Lemenih, M., Karltun, E., Olsson, M. (2005). Soil organic matter dynamics after deforestation along a farmfield chronosequence in southern highlands of Ethiopia. Agriculture, Ecosystems and Environment 109: 9-19.

Neill, C., Piccolo, M.P., Cerri, C.C., Steudler, P.A., Melillo, J.M., Brito, M. (1997). Net nitrogen mineralization and net nitrification rates in soils following deforestation for pasture across the southwestern Brazilian Amazon Basin landscape. Oecologia 110: 243-252.

Onweremadu, E.U., Ndukwu, B.N. and Ohiri K.U. (2009). Variability in particle size distribution of soils as affected by crude oil spillage. International Journal of Soil Science 1(1): 104-109.

Paul, E.A. and Clark, F.E. (1996). Soil microbiology and biochemistry London: Academic press.

PEDOWS., 1997. Zonal Atlas of West Shewa Planning and Economic Development Office for West Shewa Administrative zone. $1^{\text {st }}$ edition, Ambo, Ethiopia,
Sci. Technol. Arts Res. J., Oct-Dec 2014, 3(4): 36-41

Printing section of the Ministry of Economic Development and Cooperation

Powers, J.S. (2004). Changes in soil carbon and nitrogen after contrasting land-use transitions in northeastern Costa Rica. Ecosystems 7:134-146.

SAS. (2002). SAS System Version 9 for Microsoft Windows, SAS Institute Inc, Cary, NC, USA.

Sims, J.T. and Johnson, G.V. (1991). Micronutrient soil tests. In: J.J Mortvedi, F.R Cox, R.M. Welch editions. Soil Science Society of America. Madison, Wisconsin, U.S.A.

Teshome, Y., Heluf, G., Kibebew, K. and Sheleme, B., (2013). Impacts of Land Use on Selected Physicochemical Properties of Soils of Abobo Area, Western Ethiopia. Agriculture, Forestry and Fisheries 2(5): 177-183.

Wakene, N. (2001). Assessment of important physicochemical properties of Dystric Nitosols under different management systems in Bako area, western Ethiopia. M.Sc. Thesis Submitted to School of Graduate Studies, Alemaya University, Ethiopia.

Woldeamlak, B. and Stroosnijder, L. (2003). Effects of agro-ecological land use succession on soil properties in the Chemoga watershed, Blue Nile basin, Ethiopia. Geoderma 111: 85-98.

Yifru, A. and Taye, B. (2011). Effects of land use on soil organic carbon and nitrogen in soils of bale, southeastern Ethiopia. Journal of Tropical and Subtropical Agro Ecosystems 14: 229-235.

Yihenew, G.S. and Getachew, A. (2013). Effects of different land use systems on selected physicochemical properties of soils in Northwestern Ethiopia Journal of Agricultural Science 5(4): 112-120.

Zhang, H. and Zhang, G. (2005). Landscape-scale soil quality change under different farming systems of a tropical farm in Hainan, China. Soil Use and Management 21: 58-64. 